\title{
Women Employees, Entrepreneurs, and the Economy: A Tale of Two Ceilings
}

\author{
Pamela E. Queen \\ Morgan State University
}

Women in the workforce face multiple glass ceilings. As employees, they face leadership restrictions and earnings constraints that motivate them to become entrepreneurs. As entrepreneurs, women face impediments to capital access which stymy revenue generation, job creation, and business expansion. With more women participating in the workforce, these glass ceilings have damaging, long-term economic impacts.

Our economy depends on women in the workforce and their success is more important in a lean, green, new economy. Now, programs and policies are necessary which eliminate gender bias in the workplace, promote the involvement of women in all business sectors, prevent gender-based barriers to individual and enterprise success, and enable women to realize their potential as employees and entrepreneurs.

This paper explores distinctions in entrepreneurial motivation, industry concentration, and business performance across gender to better understand macroeconomic implications and identify policy proposals that can overcome damaging impacts to women in the workforce. This study supports an emerging research agenda on the implementation of universal policies which support women entrepreneurs and stimulate economic outcomes.

Keywords: women entrepreneurs, glass ceiling, capital financing, government policy

\section{INTRODUCTION}

"Our economy today depends upon women in the labor force. One out of three workers is a woman. Today, there are almost 25 million women employed, and their number is rising faster than the number of men in the labor force." - John F. Kennedy, 1964

Women as employees or as entrepreneurs face multiple glass ceilings; one as an employee which restricts leadership opportunities and constricts earnings that motivate her into entrepreneurship. Then, a second glass ceiling as an entrepreneur limits her access to capital that stymies business revenues, job creation, and expansion for her business enterprises. When opportunities, promotions, and subsequent pay raises are restricted, women face the first glass ceiling (Barreto, et al., 2009; Bertrand, 2018; Buckalew, et al., 2012). Out of frustration, women seek entrepreneurship, as a means to have equal opportunities, earn more, and enjoy a flexible work-life balance (Coughlin \& Thomas, 2002; Nixdorff \& Rosen, 2010; Orhan $\&$ Scott, 2001). As entrepreneurs, the second glass ceiling occurs when women encounter barriers to obtaining sufficient capital for business operation and expansion (Bosse \& Taylor, 2012). 
Women entrepreneurs are a vital economic driver in both developed or undeveloped regions (Blair, 2012). In the U. S., more than 11 million businesses are owned by women who employ about 9 million people and generate $\$ 1.7$ trillion in revenue (NAWBO, 2010). Women start thousands of new businesses daily which represents $42 \%$ of all U.S. businesses (American Express, 2019). Despite these impressive statistics, the growth and sustainability of women-owned businesses are hampered. Women-owned businesses have higher failure rates, lower business value, and limited growth potential as compared to men-owned businesses (GEM, 2020; Roper \& Scott, 2009). When women-owned businesses fail, the consequences are devastating, not only to women and their families but the entire society (Castrillion, 2019; GEM, 2020). In areas where women entrepreneurship is developed and nurtured, benefits include reduction in poverty, elevated financial conditions of families, and regional economic growth (Forbes, 2020; Minniti \& Naude, 2010).

Yet, despite these benefits, differences in measures of size, growth, and performance are observed between women-owned versus men-owned businesses in which men outperform women in all three measures. Researchers attribute these contrasts to various factors including culture, socioeconomic characteristics, external perceptions, personal preferences, or discriminatory practices that curtail entrepreneurial activity for women business owners (Cowling, \& Taylor, 2001; Hadary, 2010; Heilbrunn, 2004; Robb \& Wolken, 2002). Using Annual Survey of Entrepreneurs (ASE) data on economic and demographic characteristics of businesses with employees and receipts of $\$ 1,000$ or more, this paper explores distinctions in entrepreneurial motivation, industry concentration, and business performance across gender to better understand macroeconomic implications and identify policy proposals to overcome damaging impacts to women in the workforce.

\section{WOMEN ENTREPRENEURS - GENDER DIFFERENCES IN MOTIVATION TO START A BUSINESS}

Entrepreneurship, the desire for individuals to create new business propels economic growth. Entrepreneurial enterprises drive productivity, promote advancements, improve standards of living, increase employment and employee expertise (Audretsch \& Peña-Legazkue, 2012; GEM, 2020; Haltiwanger, et al., 2013). The U.S. leads industrialized nations with vibrant entrepreneurial activity spawn out of opportunity as a motive (Rico et al., 2017). For women versus men entrepreneurs, the primary impetus to create a business is debated. Some researchers find factors of need for success, independence, economic reward, and job satisfaction are the same for women and men entrepreneurs (Akehurst et al., 2012); while others contend that motivations are gender-based; and these differences affect entrepreneurial activities and economic outcomes (Cromie, 1987; Minetti \& Naude, 2010). More often, motives to become an entrepreneur for either men or women are not a clear choice between a "push", out of necessity reason versus a "pull", out of opportunity and desire reasons, but rather a combination of both (Orhan \& Scott, 2001; Paz \& Cabrer-Borrás, 2018).

\section{The Push Motivation}

Globally, more women than men start a business "out of necessity" and more men than women start a business to "pursue an opportunity" (Fairlie \& Fossen, 2018; Munoz, 2010). This impetus distinction to launch a business, according to the Global Entrepreneurship Monitor (GEM) is called an entrepreneurship gender gap (GEM, 2020). For women, entrepreneurship is based on necessity or "push" factors (McClelland et al., 2005; Walker \& Webster, 2007) due to financial need associated with unemployment, job frustration, low wages, difficulty finding a job, or need for a flexible work schedule, as the role of primary family caregiver is more often consigned to women (Alstete, 2003; Orhan \& Scott, 2001; Simonin, 2006). Another reason for women to become entrepreneurs is to gain control of their career prospects. Due to the first glass ceiling which causes limitations in career advancement, career growth for women is stagnated (Coughlin \& Thomas, 2002; Nixdorff \& Rosen, 2010). As employees, the first glass ceiling impedes women executives from reaching more senior management positions that push them from management into starting their own business (Bertrand, 2018; Blau \& Khan, 2017; Brush et al., 1999). The push motivation is 
commonly observed among entrepreneurs who face societal discrimination such as minorities, women, and younger entrepreneurs (Deakins \& Whittam, 2000). Becoming an entrepreneur is often the last resort for employed women pushed out of the labor market to start their businesses (Catley \& Hamilton, 1998).

Additionally, women more often than men seek business ownership for intrinsic lifestyle preferences such as flexible work schedules and better work-life balance (Manolova, et al., 2008; Rosa et al., 1994; Ufek \& Ozgen, 2001). Women who are dissatisfied with work experiences or experience inflexible, unaccommodating employers seek entrepreneurship to make a reasonable income with an amenable work schedule (McClelland et al., 2005). Entrepreneurship is a solution for women who leave the job market for family reasons. Women with family care responsibilities find business ownership conducive to earning a sustainable living and meeting family commitments (Fielden et al., 2003; Watkins \& Watkins, 1983;). Starting a new business often allows women to work in their homes. Finding a balance between family and employment is a dominant reason why women start a business (Jennings \& Mc Dougald, 2007; Manolova, et al., 2008). As Table 1 highlights, for all motivations to launch a business, women entrepreneurs rank as very important flexible hours and work-family balance.

\section{Tables}

Annual Survey of Entrepreneurs - https://www.census.gov/programs-surveys/ase.html

\section{TABLE 1}

\section{MOTIVATION TO START A BUSINESS}

\begin{tabular}{|c|c|c|c|c|c|c|}
\hline \multirow[b]{2}{*}{ Motivation to start a Business } & \multicolumn{3}{|c|}{ Women-owned } & \multicolumn{3}{|c|}{ Men-owned } \\
\hline & 2014 & 2015 & 2016 & 2014 & 2015 & 2016 \\
\hline Opportunity/Desire: Wanted to be my own boss: & & & & & & \\
\hline $\begin{array}{l}\text { Not important } \\
\text { Opportunity/Desire: Wanted to be my own boss: }\end{array}$ & $2.72 \%$ & $2.58 \%$ & $2.30 \%$ & $1.40 \%$ & $1.27 \%$ & $1.12 \%$ \\
\hline $\begin{array}{r}\text { Somewhat important } \\
\text { Opportunity/Desire: Wanted to be my own boss: }\end{array}$ & $3.56 \%$ & $3.54 \%$ & $3.30 \%$ & $3.17 \%$ & $3.11 \%$ & $2.86 \%$ \\
\hline Very important & $4.47 \%$ & $4.62 \%$ & $4.45 \%$ & $6.20 \%$ & $6.39 \%$ & $6.08 \%$ \\
\hline $\begin{array}{l}\text { Lifestyle based: Flexible hours: Not important } \\
\text { Lifestyle based: Flexible hours: Somewhat }\end{array}$ & $2.39 \%$ & $2.21 \%$ & $2.01 \%$ & $2.46 \%$ & $2.25 \%$ & $1.98 \%$ \\
\hline$i m p$ & $3.43 \%$ & $3.39 \%$ & $3.08 \%$ & $3.92 \%$ & $3.88 \%$ & $3.55 \%$ \\
\hline Lifestyle based: Flexible hours: Very important & $4.92 \%$ & $5.14 \%$ & $4.96 \%$ & $4.37 \%$ & $4.63 \%$ & $4.52 \%$ \\
\hline $\begin{array}{r}\text { Lifestyle based: Balance work and family: Not } \\
\text { important } \\
\text { Lifestyle based: Balance work and family: }\end{array}$ & $2.12 \%$ & $2.00 \%$ & $1.84 \%$ & $1.95 \%$ & $1.84 \%$ & $1.62 \%$ \\
\hline $\begin{array}{r}\text { Somewhat important } \\
\text { Lifestyle based: Balance work and family: Very }\end{array}$ & $3.20 \%$ & $3.18 \%$ & $2.92 \%$ & $4.01 \%$ & $3.98 \%$ & $3.65 \%$ \\
\hline important & $5.42 \%$ & $5.55 \%$ & $5.28 \%$ & $4.79 \%$ & $4.92 \%$ & $4.77 \%$ \\
\hline $\begin{array}{l}\text { Need-based: Greater income: Not important } \\
\text { Need-based: Greater income: Somewhat }\end{array}$ & $1.99 \%$ & $1.90 \%$ & $1.74 \%$ & $1.08 \%$ & $1.00 \%$ & $0.91 \%$ \\
\hline & $3.94 \%$ & & $3.56 \%$ & & & $3.17 \%$ \\
\hline Need-based: Greater income: Very important & $4.80 \%$ & $4.95 \%$ & $4.73 \%$ & $6.11 \%$ & $6.28 \%$ & $5.97 \%$ \\
\hline $\begin{array}{r}\text { Opportunity/Desire: Best avenue for ideas: Not } \\
\text { important } \\
\text { Opportunity/Desire: Best avenue for ideas: }\end{array}$ & $2.78 \%$ & $2.72 \%$ & $2.57 \%$ & $1.57 \%$ & $1.55 \%$ & $1.48 \%$ \\
\hline $\begin{array}{r}\text { Somewhat important } \\
\text { Opportunity/Desire: Best avenue for ideas: Very }\end{array}$ & $3.66 \%$ & $3.71 \%$ & $3.50 \%$ & $3.78 \%$ & $3.81 \%$ & $3.56 \%$ \\
\hline important & $4.30 \%$ & & $3.97 \%$ & $5.39 \%$ & $5.39 \%$ & $5.00 \%$ \\
\hline Need-based: Couldn't find a job: Not important & $8.54 \%$ & $8.46 \%$ & $7.86 \%$ & $8.30 \%$ & $8.23 \%$ & $7.66 \%$ \\
\hline
\end{tabular}




\begin{tabular}{|c|c|c|c|c|c|c|}
\hline \multirow[b]{2}{*}{ Motivation to start a Business } & \multicolumn{3}{|c|}{ Women-owned } & \multicolumn{3}{|c|}{ Men-owned } \\
\hline & 2014 & 2015 & 2016 & 2014 & 2015 & 2016 \\
\hline Need-based: Couldn't find a job: Somewhat & & & & & & \\
\hline important & $1.57 \%$ & $1.61 \%$ & $1.55 \%$ & $1.69 \%$ & $1.73 \%$ & $1.63 \%$ \\
\hline Need-based: Couldn't find a job: Very important & $0.63 \%$ & $0.66 \%$ & $0.63 \%$ & $0.76 \%$ & $0.79 \%$ & $0.75 \%$ \\
\hline $\begin{array}{l}\text { Opportunity/Desire: Work for self: Not important } \\
\text { Opportunity/Desire: Work for self: Somewhat }\end{array}$ & $4.85 \%$ & $4.67 \%$ & $4.25 \%$ & $3.52 \%$ & $3.33 \%$ & $3.04 \%$ \\
\hline $\begin{array}{r}\text { important } \\
\text { Opportunity/Desire: Work for self: Very }\end{array}$ & $3.75 \%$ & $3.79 \%$ & $3.60 \%$ & $4.12 \%$ & $4.17 \%$ & $3.89 \%$ \\
\hline important & $2.14 \%$ & $2.29 \%$ & $2.19 \%$ & $3.11 \%$ & $3.26 \%$ & $3.11 \%$ \\
\hline $\begin{array}{r}\text { Opportunity/Desire: Start my own business: Not } \\
\text { important }\end{array}$ & $4.01 \%$ & $3.96 \%$ & $3.61 \%$ & $2.35 \%$ & $2.29 \%$ & $2.05 \%$ \\
\hline $\begin{array}{r}\text { Somewhat important } \\
\text { Opportunity/Desire: Start my own business: Very }\end{array}$ & $3.53 \%$ & $3.58 \%$ & $3.32 \%$ & $3.70 \%$ & $3.71 \%$ & $3.43 \%$ \\
\hline important & $3.19 \%$ & $3.19 \%$ & $3.10 \%$ & $4.69 \%$ & $4.75 \%$ & $4.56 \%$ \\
\hline $\begin{array}{r}\text { Tradition based: Friend or family role model: Not } \\
\text { important }\end{array}$ & $5.47 \%$ & $5.37 \%$ & $4.84 \%$ & $4.98 \%$ & $4.88 \%$ & $4.36 \%$ \\
\hline $\begin{array}{r}\text { Somewh } \\
\text { Tradition hased. Friond }\end{array}$ & $2.80 \%$ & $2.86 \%$ & $2.71 \%$ & $3.05 \%$ & $3.11 \%$ & $2.92 \%$ \\
\hline $\begin{array}{r}\text { Tradition based: Friend or family role model: } \\
\text { Very important }\end{array}$ & $2.47 \%$ & $2.51 \%$ & $2.50 \%$ & $2.72 \%$ & $2.77 \%$ & $2.77 \%$ \\
\hline Other: Not important & $2.64 \%$ & $2.65 \%$ & $8.16 \%$ & $2.55 \%$ & $2.56 \%$ & $8.11 \%$ \\
\hline Other: Somewhat important & $0.29 \%$ & $0.30 \%$ & $0.74 \%$ & $0.34 \%$ & $0.33 \%$ & $0.83 \%$ \\
\hline Other: Very important & $0.44 \%$ & $0.39 \%$ & $0.74 \%$ & $0.33 \%$ & $0.29 \%$ & $0.67 \%$ \\
\hline
\end{tabular}

\section{The Pull Motivation}

Entrepreneurs are also motivated by "pull" factors (McClelland et al., 2005) associated with opportunity, choice, and aspiration (Deakins \& Whittam, 2000; Orhan \& Scott, 2001). These drivers are characterized by a desire for independence, accomplishment, autonomy, and being one's boss (Alstete, 2002; Orhan \& Scott, 2001). Other motives associated with pull drivers are wanting a challenge, developing skills and broader experiences, gaining greater social status, and influencing one's destiny (Simonin, 2006; Akehurst, et al., 2012). For women, frequent "pull" drivers are need for independence and the challenge of business ownership (Hughes, 2003; Kirkwood, 2009).

As shown in Table 1, pull motives of desire to be one's boss, the best venue for ideas, desire to work for self, and opportunity to start one's own business are more important to men compared to women entrepreneurs. Although not captured in Table 1, the literature suggests that women are also motivated by the social contribution their business can make to society (Orhan \& Scott, 2001). Women as compared to men place greater emphasis on interpersonal factors; and women derive satisfaction from affinity to employees and customers in pursuit of social objectives of "making a difference" (Bird \& Brush, 2002; Still \& Timms, 2000).

\section{WOMEN ENTREPRENEURS - IMPACT OF GENDER DIFFERENCES ON ACCESS TO CAPITAL}

When women entrepreneurs face systemic, obstructions to financing, this is termed the second glass ceiling (Bosse \& Taylor, 2012). These capital accessibility barriers for women entrepreneurs include tighter credit availability (Bellucci et al., 2010); lower loan approval rates (Muravyev et al., 2009); and less favorable financial terms (Akehurst et al., 2012) as compared to men. The impact results in limited choices 
of business enterprises, a fewer number of employees, less revenue, and smaller business growth (Brush, et al, 2019; Hisrich \& Brush, 1984; Verheul \& Thurik, 2001).

\section{Impact on Source and Amount of Capital}

Lack of capital during the initial stages of business start-up, which many women entrepreneurs face has damaging, long-term impacts (Akekurst, et al, 2012; Sena et al., 2012; Ufuk \& Ozgen, 2001). Obtaining capital from traditional financial institutions is challenging for new business start-ups, especially for women entrepreneurs who lack credit history, operate businesses on a shoestring, and have constrained cash flow (Carter \& Van Auken, 2007; Shaw et al., 2009). Women also face discriminatory treatment from banks (Brush, et al, 2019; Treichel \& Scott, 2006). Therefore, women entrepreneurs have a greater reliance on credit cards, personal savings, and family members to finance their businesses (Manolova, et al., 2006; Scherer et al., 1990; Shaw et al., 2009; Verheul \& Thurik, 2001). Furthermore, some women entrepreneurs do not perceive a necessity for external capital (Orser et al., 2006), as financial entry barriers are lower for small, service-oriented, and inexpensive business ventures that women entrepreneurs predominately pursue (Carter and Van Auken, 2007; Heilbrunn, 2004). As Table 2 shows for both women and men, the source of capital from personal and family assets is higher compared to other sources of capital; however, for women the percentages are considerably higher.

One plausible explanation for capital access differences between men and women entrepreneurs is the liability of newness (Stinchombe, 1965) in which a novice, unestablished entity has more difficulty obtaining capital (Hill, et al., 2006; Marlow \& Patton, 2005). Also, entrepreneurs, especially women have difficulty obtaining sufficient capital from financial institutions because they lack start-up seed money (Storey, 1994), lack family financial resources (Akekurst, et al., 2012), and lack notable management skills (Pellegrino and Reece, 1982). Yet, despite these concerns, women business owners have no dissimilarities in terms of bill payment behavior, financial hardship, and overall creditworthiness (NAWBO, 2010). Nevertheless, as compared to men, women have fewer financial assets at business start-up (Bosse \& Taylor, 2012; Carter, 2000; Nixdorff \& Rosen, 2010). As Table 3 highlights, both men and women start businesses with small financial amounts; however, women more than men entrepreneurs start their business with less than $\$ 5,000$ start-up money. The reason for this observation is that women tend to pursue low-cost business ventures by choice, or limited access to capital forces their decisions to pursue low start-up capital businesses (Anna, et al., 2000; Akehurst, et al., 2012; Hadary, 2010; Loscocco, \& Robinson, 1991).

TABLE 2

SOURCE OF BUSINESS START-UP CAPITAL

\begin{tabular}{|c|c|c|c|c|c|c|}
\hline \multirow[b]{2}{*}{ Start-up Capital Source } & \multicolumn{3}{|c|}{ Women-owned } & \multicolumn{3}{|c|}{ Men-owned } \\
\hline & 2014 & 2015 & 2016 & 2014 & 2015 & 2016 \\
\hline Personal/family savings of owner(s) & $45.12 \%$ & $46.01 \%$ & $47.00 \%$ & $44.99 \%$ & $46.02 \%$ & $46.81 \%$ \\
\hline Personal/family assets other than savings & & & & & & \\
\hline of owner $(s)$ & $6.75 \%$ & $6.87 \%$ & $6.19 \%$ & $6.51 \%$ & $6.46 \%$ & $5.88 \%$ \\
\hline Personal/family home equity loan & $5.32 \%$ & $5.23 \%$ & $4.80 \%$ & $4.60 \%$ & $4.39 \%$ & $4.08 \%$ \\
\hline Personal credit card(s) carrying balances & $8.56 \%$ & $8.30 \%$ & $7.53 \%$ & $6.64 \%$ & $6.68 \%$ & $6.16 \%$ \\
\hline Business credit card(s) carrying balances & $4.21 \%$ & $4.18 \%$ & $4.02 \%$ & $3.49 \%$ & $3.61 \%$ & $3.38 \%$ \\
\hline $\begin{array}{r}\text { Business loan from federal, state, or local } \\
\text { government }\end{array}$ & $0.31 \%$ & $0.28 \%$ & $0.37 \%$ & $0.27 \%$ & $0.26 \%$ & $0.29 \%$ \\
\hline $\begin{array}{l}\text { Government-guaranteed business loan } \\
\text { from a bank or financial institution }\end{array}$ & $1.44 \%$ & $1.44 \%$ & $1.37 \%$ & $1.12 \%$ & $1.12 \%$ & $1.12 \%$ \\
\hline $\begin{array}{r}\text { Business loan from a bank or financial } \\
\text { institution }\end{array}$ & $10.34 \%$ & $10.32 \%$ & $10.11 \%$ & $12.70 \%$ & $12.43 \%$ & $12.01 \%$ \\
\hline $\begin{array}{r}\text { Business loan/investment from } \\
\text { family/friends }\end{array}$ & $3.42 \%$ & $3.18 \%$ & $3.08 \%$ & $3.37 \%$ & $3.29 \%$ & $3.16 \%$ \\
\hline Investment by venture capitalist(s) & $0.20 \%$ & $0.22 \%$ & $0.20 \%$ & $0.42 \%$ & $0.38 \%$ & $0.37 \%$ \\
\hline
\end{tabular}




\begin{tabular}{r|rrrrrrr} 
& \multicolumn{3}{c}{ Women-owned } & \multicolumn{3}{c}{ Men-owned } \\
Start-up Capital Source & 2014 & 2015 & 2016 & 2014 & 2015 & 2016 \\
\hline Grants & $0.20 \%$ & $0.18 \%$ & $0.20 \%$ & $0.12 \%$ & $0.12 \%$ & $0.12 \%$ \\
\hline Other source(s) of capital & $2.20 \%$ & $2.04 \%$ & $1.95 \%$ & $2.33 \%$ & $2.21 \%$ & $2.11 \%$ \\
Don't know & $5.20 \%$ & $5.01 \%$ & $5.77 \%$ & $7.54 \%$ & $7.23 \%$ & $8.26 \%$ \\
None needed & $6.74 \%$ & $6.75 \%$ & $7.42 \%$ & $5.88 \%$ & $5.79 \%$ & $6.27 \%$ \\
Source: Annual Survey of Entrepreneurs (ACE) & - https://www.census.gov/programs-surveys/ase.html
\end{tabular}

TABLE 3

BUSINESS START-UP CAPITAL AMOUNT

\begin{tabular}{|c|c|c|c|c|c|c|}
\hline \multirow[b]{2}{*}{ Start-up Capital Amount } & \multicolumn{3}{|c|}{ Women-owned } & \multicolumn{3}{|c|}{ Men-owned } \\
\hline & 2014 & 2015 & 2016 & 2014 & 2015 & 2016 \\
\hline Less than $\$ 5,000$ & $18.10 \%$ & $18.30 \%$ & $18.70 \%$ & $14.80 \%$ & $14.70 \%$ & $15.00 \%$ \\
\hline$\$ 5,000$ to $\$ 9,999$ & $9.40 \%$ & $9.40 \%$ & $9.40 \%$ & $8.30 \%$ & $8.40 \%$ & $8.40 \%$ \\
\hline$\$ 10,000$ to $\$ 24,999$ & $12.40 \%$ & $12.40 \%$ & $12.10 \%$ & $12.00 \%$ & $12.10 \%$ & $11.80 \%$ \\
\hline$\$ 25,000$ to $\$ 49,999$ & $9.80 \%$ & $10.10 \%$ & $9.60 \%$ & $9.30 \%$ & $9.20 \%$ & $8.90 \%$ \\
\hline$\$ 50,000$ to $\$ 99,999$ & $10.30 \%$ & $9.70 \%$ & $9.80 \%$ & $10.00 \%$ & $9.70 \%$ & $9.50 \%$ \\
\hline$\$ 100,000$ to $\$ 249,999$ & $9.40 \%$ & $9.50 \%$ & $9.10 \%$ & $9.80 \%$ & $10.10 \%$ & $9.90 \%$ \\
\hline$\$ 250,000$ to $\$ 999,999$ & $5.50 \%$ & $5.60 \%$ & $5.70 \%$ & $6.70 \%$ & $6.90 \%$ & $6.80 \%$ \\
\hline$\$ 1,000,000$ to $\$ 2,999,999$ & $0.90 \%$ & $0.90 \%$ & $0.90 \%$ & $1.60 \%$ & $1.60 \%$ & $1.70 \%$ \\
\hline$\$ 3,000,000$ or more & $0.30 \%$ & $0.30 \%$ & $0.30 \%$ & $0.70 \%$ & $0.70 \%$ & $0.70 \%$ \\
\hline Don't know & $14.10 \%$ & $13.70 \%$ & $14.00 \%$ & $18.40 \%$ & $18.20 \%$ & $18.70 \%$ \\
\hline Not applicable & $9.90 \%$ & $9.90 \%$ & $10.50 \%$ & $8.40 \%$ & $8.30 \%$ & $8.70 \%$ \\
\hline
\end{tabular}

\section{Impact on Business Industry Concentration}

Evidence of the second glass ceiling occurs when women adjust their aspirations to start enterprises in the service sector due to low capital requirements and less competition (Akehurst, et al., 2012; Anna, et al., 2000; Hadary, 2010; Loscocco and Robinson, 1991). The type of businesses owned by women contrasts from those owned by men (Allen et al., 2007; Coleman, 2000; Orser et al., 2006;) with women-owned businesses more prevalent in sectors that have low barriers to entry and lower revenue generation (Lerner \& Almor, 2002). The concentration of women entrepreneurs in service industries is not surprising as these sectors represent areas of traditional employment for women; and their skills are a naturally learned extension of gender socialization (Birley, 1989). As compared to men, women-owned businesses are primarily in retail and service industries in which businesses are smaller by the number of employees and revenue; whereas, men-owned businesses are predominately in construction and manufacturing sectors which have higher revenue (NAWBO, 2010; American Express, 2019). These distinctions are attributed to a greater proportion of women employed in service industries due to lack of manufacturing industry experience (Anna, et al., 2000), women having more administrative experience in service industries (Coughlin \& Thomas, 2002), and greater attraction for women to low capital intensive industries (Robb \& Coleman, 2002; Robb \& Wolken, 2014; Roper \& Scott, 2009). Contrary to research, Table 4 highlights that overwhelmingly men entrepreneurs own the majority of businesses in both manufacturing and service industries with women having a slightly higher percentage of ownership in the education sector. 


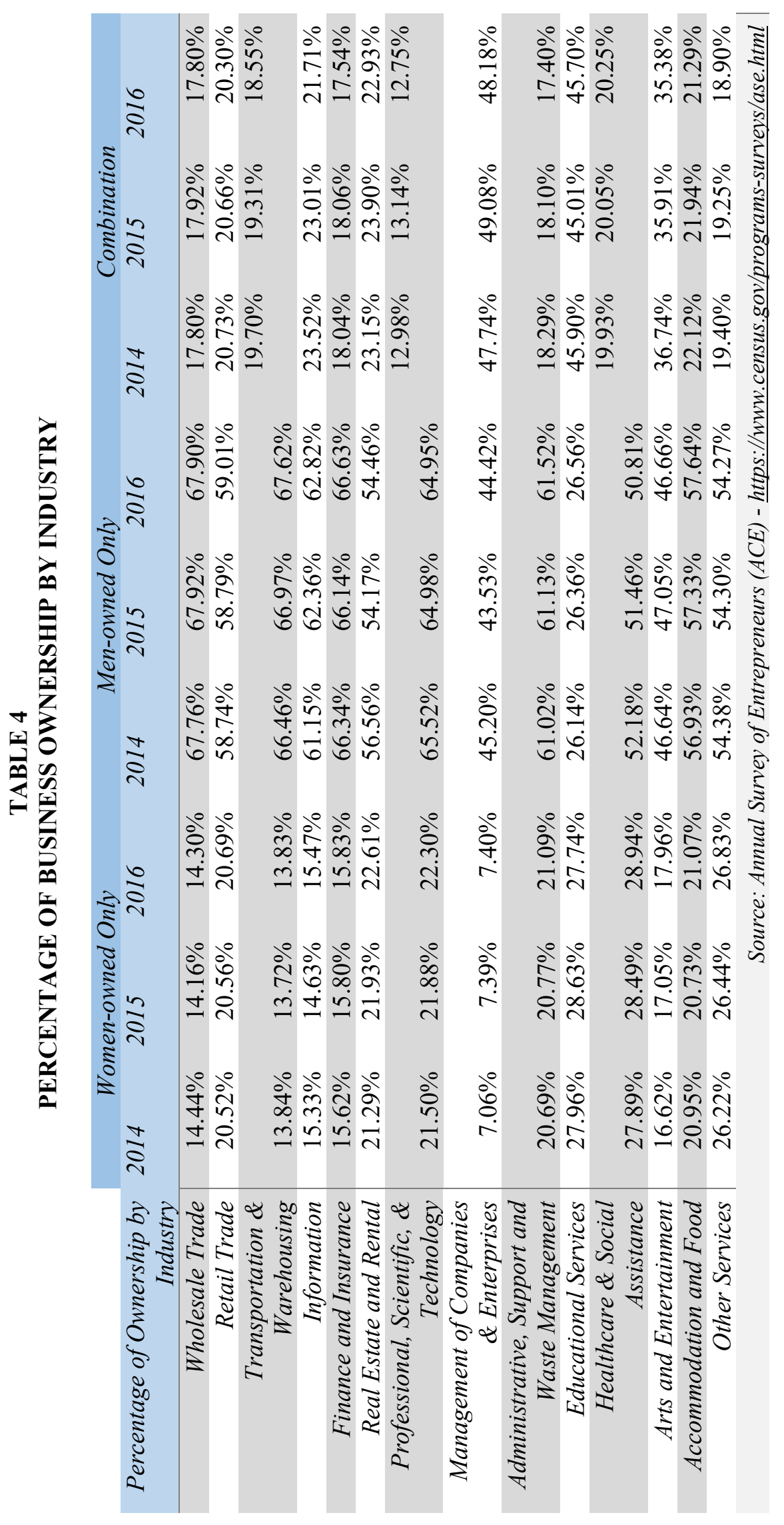

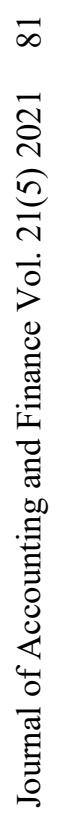




\section{Impact on Business Size}

As compared to men, women-owned businesses are smaller in size, as measured by both revenue and number of employees (Akehurst, et al., 2012; Cowling \& Taylor, 2001). Sales of women-owned businesses are approximately 80\% lower than sales of men-owned businesses (Gatewood et al., 2002). The firm size wage effect (FSWE) for businesses is often attributed to the greater difficulty encountered by women entrepreneurs in obtaining resources to finance their enterprises (Hollister, 2004). Women entrepreneurs, as compared to men, more often use their savings and loans from family (Scherer et al., 1990). Other researchers attribute differences in business size to dissimilar motivation, intention, and attitudes about business growth for women as compared to men (Du Rietz \& Henrekson, 2000). Women entrepreneurs often embrace smaller size firms that satisfy family-life balance preferences and provide better connections with employees. As Table 5 emphasizes, more women-owned businesses have four or fewer employees in comparison to men-owned businesses. More men-owned businesses have employees ranging from 5 or more to over 500. However, the crux of this gender quandary is not explained. Researchers find that for the same industry, sales for women-owned businesses are lower as compared to men-owned businesses (Chaganti \& Parasuraman, 1996). Using sales receipts as a measure of firm size, Table 6 reinforces that women-owned businesses are smaller. Women-owned firms have a larger percentage of firms with receipts of $\$ 249,999$ or less; whereas, men-owned businesses have more firms with receipts of $\$ 250,000$ and more.

TABLE 5

\section{BUSINESS SIZE BY NUMBER OF EMPLOYEES}

\begin{tabular}{|c|c|c|c|c|c|c|}
\hline \multirow[b]{2}{*}{ Number of Employees } & \multicolumn{3}{|c|}{ Women-owned } & \multicolumn{3}{|c|}{ Men-owned } \\
\hline & 2014 & 2015 & 2016 & 2014 & 2015 & 2016 \\
\hline Firms with no employees & $11.02 \%$ & $10.76 \%$ & $10.72 \%$ & $10.14 \%$ & $9.91 \%$ & $9.81 \%$ \\
\hline Firms with 1 to 4 employees & $55.10 \%$ & $55.26 \%$ & $55.12 \%$ & $51.33 \%$ & $51.38 \%$ & $51.19 \%$ \\
\hline Firms with 5 to 9 employees & $16.99 \%$ & $16.99 \%$ & $16.88 \%$ & $17.47 \%$ & $17.43 \%$ & $17.49 \%$ \\
\hline Firms with 10 to 19 employees & $9.74 \%$ & $9.99 \%$ & $9.95 \%$ & $10.73 \%$ & $10.71 \%$ & $10.88 \%$ \\
\hline Firms with 20 to 49 employees & $5.22 \%$ & $5.08 \%$ & $5.28 \%$ & $6.94 \%$ & $7.14 \%$ & $7.15 \%$ \\
\hline Firms with 50 to 99 employees & $1.21 \%$ & $1.17 \%$ & $1.24 \%$ & $2.05 \%$ & $2.11 \%$ & $2.09 \%$ \\
\hline Firms with 100 to 249 employees & $0.53 \%$ & $0.55 \%$ & $0.59 \%$ & $0.95 \%$ & $0.92 \%$ & $0.99 \%$ \\
\hline Firms with 250 to 499 employees & $0.11 \%$ & $0.13 \%$ & $0.15 \%$ & $0.24 \%$ & $0.24 \%$ & $0.25 \%$ \\
\hline Firms with 500 employees or more & $0.08 \%$ & $0.07 \%$ & $0.08 \%$ & $0.16 \%$ & $0.16 \%$ & $0.16 \%$ \\
\hline
\end{tabular}

TABLE 6

\section{BUSINESS SALES/RECEIPTS}

\begin{tabular}{|c|c|c|c|c|c|c|}
\hline & \multicolumn{3}{|c|}{ Women-owned } & \multicolumn{3}{|c|}{ Men-owned } \\
\hline Business Sales/Receipts & 2014 & 2015 & 2016 & 2014 & 2015 & 2016 \\
\hline Firms with sales/receipts of less than $\$ 10,000$ & $2.42 \%$ & $2.35 \%$ & $2.42 \%$ & $1.67 \%$ & $1.63 \%$ & $1.55 \%$ \\
\hline Firms with sales/receipts of $\$ 10,000$ to & & & & & & \\
\hline$\$ 49,999$ & $10.24 \%$ & $10.09 \%$ & $10.05 \%$ & $6.21 \%$ & $6.14 \%$ & $6.15 \%$ \\
\hline $\begin{array}{r}\text { Firms with sales/receipts of } \$ 50,000 \text { to } \\
\$ 99,999\end{array}$ & $12.95 \%$ & $12.69 \%$ & $12.33 \%$ & $8.47 \%$ & $8.35 \%$ & $8.14 \%$ \\
\hline $\begin{array}{r}\text { Firms with sales/receipts of } \$ 100,000 \text { to } \\
\$ 249,999\end{array}$ & $24.32 \%$ & $23.80 \%$ & $23.47 \%$ & $19.70 \%$ & $19.23 \%$ & $18.96 \%$ \\
\hline $\begin{array}{r}\text { Firms with sales/receipts of } \$ 250,000 \text { to } \\
\$ 499,999\end{array}$ & $19.11 \%$ & $19.43 \%$ & $19.52 \%$ & $19.40 \%$ & $19.52 \%$ & $19.54 \%$ \\
\hline $\begin{array}{r}\text { Firms with sales/receipts of } \$ 500,000 \text { to } \\
\$ 999,999\end{array}$ & $13.95 \%$ & $14.27 \%$ & $14.41 \%$ & $16.99 \%$ & $16.85 \%$ & $17.06 \%$ \\
\hline $\begin{array}{r}\text { Firms with sales/receipts of } \$ 1,000,000 \text { or } \\
\text { more }\end{array}$ & $17.01 \%$ & $17.37 \%$ & $17.81 \%$ & $27.56 \%$ & $28.27 \%$ & $28.60 \%$ \\
\hline
\end{tabular}




\section{Impact on Business Growth}

For women entrepreneurs, business growth is hampered by access to capital challenges. Women-owned businesses grow less (Du Reitz \& Henrekson, 2000; Coleman, 2007) and are less profitable (Robb and Wolken, 2002) because access to external funding is constricted (Agier \& Szafarz, 2013; Birley, 1989; Bosse \& Taylor, 2012). These financing barriers result from limited networks, no relationships with lenders, or higher loan denial rates (Bellucci, et al., 2010; Madill, et al., 2006; McClelland, et al., 2005). With limited prior business experience in comparison to men, women entrepreneurs lack broad social and business networks, especially with lender-borrower relationships (Heilbrunn, 2004; Madill et al., 2006; Manolova et al., 2012; Roper \& Scott, 2009). When banking relationships are strong, small businesses obtain more capital at lower financing costs (Cavalluzzo, et al., 2002). Furthermore, women business owners are less likely than other demographic groups to obtain desired terms for loans. This is explained by inadequate networks and less routine dealings with financial suppliers (Madill et al., 2006; McClelland, et al., 2005; Roper \& Scott, 2009). Table 7 highlights that men entrepreneurs, as compared to women entrepreneurs are more likely to receive the total amount requested from banks, credit unions, and other financial institutions. With an access to capital gender gap at business start-up in loan size, harsher loan conditions, and higher denial rates for external financing, women business owners are often reluctant to seek financing for expansion and business growth (Agier \& Szafarz, 2013; Cavalluzzo, et al., 2002; Roper \& Scott, 2009).

\section{TABLE 7}

\section{EXPANSION CAPITAL RELATIONSHIP}

\begin{tabular}{|c|c|c|c|c|c|c|}
\hline & \multicolumn{3}{|c|}{ Women-owned } & \multicolumn{3}{|c|}{ Men-owned } \\
\hline Expansion Capital Relationship & 2014 & 2015 & 2016 & 2014 & 2015 & 2016 \\
\hline $\begin{array}{r}\text { Other owner(s) (if applicable): Received } \\
\text { total amount requested }\end{array}$ & $0.67 \%$ & $0.76 \%$ & $0.65 \%$ & $0.89 \%$ & $0.96 \%$ & $0.96 \%$ \\
\hline $\begin{array}{r}\text { Other owner(s) (if applicable): Did not } \\
\text { receive total amount requested }\end{array}$ & $0.46 \%$ & $0.47 \%$ & $0.38 \%$ & $0.51 \%$ & $0.50 \%$ & $0.44 \%$ \\
\hline $\begin{array}{r}\text { Other owner(s) (if applicable): Did not } \\
\text { attempt to establish this new funding } \\
\text { relationship }\end{array}$ & $98.87 \%$ & $98.77 \%$ & $98.97 \%$ & $98.60 \%$ & $98.54 \%$ & $98.60 \%$ \\
\hline $\begin{array}{r}\text { Banks, credit unions, or other financial } \\
\text { institutions: Received total amount } \\
\text { requested }\end{array}$ & $7.50 \%$ & $7.45 \%$ & $7.26 \%$ & $10.24 \%$ & $10.22 \%$ & $10.21 \%$ \\
\hline $\begin{array}{r}\text { Banks, credit unions, or other financial } \\
\text { institutions: Did not receive total amount } \\
\text { requested }\end{array}$ & $3.63 \%$ & $3.41 \%$ & $2.92 \%$ & $3.51 \%$ & $3.43 \%$ & $3.02 \%$ \\
\hline $\begin{array}{r}\text { Banks, credit unions, or other financial } \\
\text { institutions: Did not attempt to establish } \\
\text { this new funding relationship }\end{array}$ & $88.87 \%$ & $89.14 \%$ & $89.82 \%$ & $86.25 \%$ & $86.35 \%$ & $86.77 \%$ \\
\hline $\begin{array}{r}\text { Angel investors: Received total amount } \\
\text { requested }\end{array}$ & $0.21 \%$ & $0.18 \%$ & $0.22 \%$ & $0.26 \%$ & $0.28 \%$ & $0.34 \%$ \\
\hline $\begin{array}{r}\text { Angel investors: Did not receive total } \\
\text { amount requested }\end{array}$ & $0.24 \%$ & $0.17 \%$ & $0.22 \%$ & $0.31 \%$ & $0.30 \%$ & $0.26 \%$ \\
\hline $\begin{array}{l}\text { Angel investors: Did not attempt to } \\
\text { establish this new funding relationship }\end{array}$ & $99.55 \%$ & $99.65 \%$ & $99.56 \%$ & $99.43 \%$ & $99.42 \%$ & $99.41 \%$ \\
\hline $\begin{array}{r}\text { Venture capitalists: Received total amount } \\
\text { requested }\end{array}$ & $0.16 \%$ & $0.14 \%$ & $0.17 \%$ & $0.22 \%$ & $0.26 \%$ & $0.31 \%$ \\
\hline
\end{tabular}




\begin{tabular}{|c|c|c|c|c|c|c|}
\hline $\begin{array}{r}\text { Venture capitalists: Did not receive total } \\
\text { amount requested }\end{array}$ & $0.23 \%$ & $0.20 \%$ & $0.23 \%$ & $0.31 \%$ & $0.30 \%$ & $0.25 \%$ \\
\hline $\begin{array}{l}\text { Venture capitalists: Did not attempt to } \\
\text { establish this new funding relationship }\end{array}$ & $99.61 \%$ & $99.67 \%$ & $99.60 \%$ & $99.47 \%$ & $99.44 \%$ & $99.43 \%$ \\
\hline $\begin{array}{r}\text { Crowd funding platform: Received total } \\
\text { amount requested }\end{array}$ & $0.14 \%$ & $0.18 \%$ & $0.20 \%$ & $0.15 \%$ & $0.19 \%$ & $0.25 \%$ \\
\hline $\begin{array}{r}\text { Crowd funding platform: Did not receive } \\
\text { total amount requested }\end{array}$ & $0.17 \%$ & $0.16 \%$ & $0.17 \%$ & $0.15 \%$ & $0.14 \%$ & $0.14 \%$ \\
\hline $\begin{array}{l}\text { Crowd funding platform: Did not attempt } \\
\text { to establish this new funding relationship }\end{array}$ & $99.69 \%$ & $99.66 \%$ & $99.63 \%$ & $99.71 \%$ & $99.67 \%$ & $99.62^{\circ}$ \\
\hline
\end{tabular}

\section{DISCUSSION}

\section{Women as Employees and Entrepreneurs - Economic Impact}

In the U.S., women are an important economic engine representing a large percentage of the workforce. Yet, despite decades of progress, disparities in wage earnings for women persist, as employees (Bertrand, 2018) and in revenue generation, as entrepreneurs (Bosse \& Taylor, 2012). Since 1990, the U.S. has become a service economy with women as the largest proportion of employees (GEM, 2020). The concentration of women in service industries is predictable, as these sectors traditionally employ women and are an extension of gender socialization (Birley, 1989; Scherer, et al., 1990). Despite anti-employment discrimination laws, employment patterns in certain service sectors remain segregated by gender with women having lower skills and inferior job status (Bruni et al., 2004). These variations in employment practices contribute to women employees having lower wages and women entrepreneurs having enterprises with lower revenue generation potential (Akehurst, et al., 2012; Anna, et al., 2000; Lerner \& Almor, 2002).

The first glass ceiling is an invisible barrier for women to achieve professional job promotions which contributes to high poverty rates, less wealth creation, and limited professional progress for women as compared to men. For every dollar earned by men, women working full-time, year-round earned approximately 80 cents (Hegewisch \& DuMonthier, 2016) and these gender pay differences exist across all industries, occupations, and employment levels. For U.S. working women, ending wage inequity would drop poverty rates for women from $10.8 \%$ to $4.4 \%$, generate $\$ 512.6$ billion more in income, and represent about a $3 \%$ increase in the U.S. gross domestic product (Bertrand, 2018).

The second glass ceiling occurs when women business owners face barriers in obtaining external funding which stifles job creation, confines business size, and restricts women entrepreneurs to low capital entry industries. These industries with low capital for start-up traditionally have lower employee wages and lower revenue generation which in turn limits wealth creation for women (Alsos, et al., 2006; Bosse \& Taylor, 2012; NAWBO, 2010). Furthermore, when the type of business that women entrepreneurs pursue are hampered, their survival rates, potential profits, and sales growth are lower. These detrimental outcomes directly impact local economies (Alsos, et al., 2006; Robb \& Wolken, 2002).

Today, small businesses are even more important to economies with enterprises restructuring to a lean and green, new economy that yields greater efficiencies (Anna, et al., 2000). According to the Small Business Administration, America's small businesses create more new jobs and generate more than half of the nation's GDP. Women entrepreneurs greatly contribute to this progress (American Express, 2019; Bosse and Taylor, 2012). Women entrepreneurs make distinct beneficial economic differences in their communities (McClelland, et al., 2005). Therefore, greater emphasis is needed to address the firm size wage effect (FSWE) puzzle in which small businesses on average pay lower wages than large businesses for workers with equivalent skills (Hollister, 2004). Detrimental impacts of FSWE coupled with low-paying, service industry jobs can result in lasting, significant economic downturns, especially as women dominate the labor force. 


\section{Women as Employees and Entrepreneurs - Policy Implications}

With the growing number of women in the labor force as employees and entrepreneurs coupled with increases in gender wage gaps, limited promotion to corporate leadership, and differences in entrepreneurial activity due to the gender of business owners (Vossenberg, 2013), universal policies are necessary to address these social disparities. The requisite policies must include initiatives to increase the presence of women in leadership roles with training, mentoring, and access to networks (Bruckmuller, et al., 2014) which will address gender inequality throughout all organizational levels. As organizations debate strategies of quotas versus targets to increase women in leadership (Klettner, et al., 2016), one policy approach compels companies to disclose the number of women at senior ranks and provide a diversity agenda with measurable objectives in their annual report; or otherwise, disclose the rationale for not complying. This approach provides transparency for investors into corporate efforts to address gender disparities in leadership and professional growth. However, with the slow pace of progress in gender diversity in leadership, some companies are embracing less popular quota policies when plans, policies, and initiatives are not achieving desired goals. Although a debatable policy, research shows that $47 \%$ of businesses support the introduction of quotas, especially for executive boards and recruitment efforts (Thornton, 2018).

Policies that expand the pool of investors who understand uncertainty and risk-taking associated with entrepreneurship and long-term horizon associated with entrepreneurial endeavors (Kerr \& Nanda, 2009) are paramount for supporting women entrepreneurs. Especially for women entrepreneurs with greater loan denials from conventional sources and less venture capital backing, policies to entice other funding channels are crucial to help fill gaps in obtaining capital (Stam, 2015). Therefore, governments working with communities must develop innovative funding streams and build collaborative investment funds that will expand businesses, accelerate product development, and extend supplier relationships for women business owners. Government venture capital programs with collaborative private sector involvement have proven to be most effective with producing transformative outcomes (Lerner, 2009).

Glass ceiling occurrences are attributed to inadequate training or lack of supportive resources for women to succeed (Bruckmuller, et al., 2014). More gender diversity training will inform senior management of the presence of subtle forms of gender discrimination within their ranks and instruct managers on how best to combat these workplace biases. With greater access to social resources, mentoring, and career planning for women leaders, the glass ceiling barriers can be broken (Hersby et al., 2009). Often male colleagues lack awareness of dissimilar experiences and attitudes that exist for women as compared to men employees. Organizations must enact policies that increase mentorship and access to broader networks in order to remove barriers that limit advancement for women (Bruckmuller, et al., 2014).

\section{CONCLUSION}

\section{“When women do better, economies do better" Christine LaGarde, 2013}

Researchers highlight that the economic contributions created by women business-owners has been downplayed; and their influences require more study. After examining six decades of federal policy intent on promoting business ownership and entrepreneurship of women, Pandley and Amezcua (2020) conclude that little has changed to achieve intended outcomes; and they call for more studies of effective government policy that supports women business owners and entrepreneurs. Future research directions must pivot from viewing the motivation, acumen, and ability of women entrepreneurs, as subordinate and less important, but rather at least complementary to efforts and resources endowed to men (Ahl, 2006). This paper adds to the chorus calling for an emerging research agenda on universal policies to promote women entrepreneurship; and a call for greater analysis of the impact of women entrepreneurs on economic outcomes (Vossenberg, 2013).

In the U.S., the impact of the first glass ceiling is evidenced by only $6 \%$ of women have earnings in the top 20\% wage range of men (Bertrand, 2018). The second glass ceiling obstructs access to capital and financial networks for women entrepreneurs to adequately start and amply grow new businesses (Bosse \& Taylor, 2012). When these barriers are removed, more economic growth is realized. Governments can play 
a critical role in fostering entrepreneurship. Effective policies must be well-designed to avoid harmful, unintentional results. These policies must ensure allocation of resources is fair, sufficient and obtainable for all entrepreneurs, especially nascent, small businesses.

Entrepreneurial success requires more than individual desire and drive to succeed. Therefore, governments can aid entrepreneurs with promoting supportive environments with abundant social networks, greater resources, and ample customers (Leyden, 2016). For policymakers, understanding the relationship between entrepreneurship and economic development is essential in creating thriving business environments. When policymakers cultivate a balanced approach to nurturing entrepreneurship, positive economic and societal outcomes result. Especially for women entrepreneurs, implemented policies must coalesce well-connected, networks of seasoned entrepreneurs, investors, advisors, mentors, and supporters who nurture entrepreneurial activities that yield broad economic benefits (Stam \& Spigel, 2016). The goal for policymakers is to implement comprehensive policies that do not inadvertently conflict with or cannibalize existing laws, but rather works well for all entrepreneurs. Subsequently, when women entrepreneurs do better, then economies will do better.

\section{REFERENCES}

Agier, I., \& Szafarz, A. (2013). Microfinance and Gender: Is There a Glass Ceiling on Loan Size? World Development, 42, 65-181. ISSN 0305-750X. https://doi.org/10.1016/j.worlddev.2012.06.016

Ahl, H. (2006). Why research on women entrepreneurs needs new directions. Entrepreneurship Theory and Practice, 30, 595-621.

Akehurst, G., Simarro, E., \& Mas-Tur, A. (2012). Women entrepreneurship in small service firms: Motivations, barriers, and performance. The Service Industries Journal, 32(15), 2489. Retrieved from https://www-proquest-com.proxy-ms.researchport.umd.edu/scholarly-journals/womenentrepreneurship-small-service-firms/docview/1038937296/se-2?accountid=12557

Allen, W.D., \& Hall, T.W. (2007). Innovation, managerial effort, and start-up performance. The Journal of Entrepreneurial Finance \& Business Ventures, 12(2), 87-118. Retrieved from https://wwwproquest-com.proxy-ms.researchport.umd.edu/scholarly-journals/innovation-managerial-effortstart-up-performance/docview/1030134683/se-2?accountid=12557

Alsos, G.A., Isaksen, E.J., \& Ljunggren, E. (2006). New venture financing and subsequent business growth in men- and women-led businesses: ET\&P. Entrepreneurship Theory and Practice, 30(5), 667686. http://dx.doi.org.proxy-ms.researchport.umd.edu/10.1111/j.1540-6520.2006.00141.x

Alstete, J. (2003). On becoming an entrepreneur: An evolving typology. International Journal of Entrepreneurial Behaviour and Research, 8(4), 222-34.

American Express Reports state of women-owned businesses report. (2019, September 29). Manufacturing Close-Up. Retrieved from https://www-proquest-com.proxyms.researchport.umd.edu/wire-feeds/american-express-reports-state-womenowned/docview/2298973948/se-2?accountid=12557

Anna, A., Chandler, G., Jansen, E., \& Mero, N. (2000) Women business owners in traditional and nontraditional industries. Journal of Business Venturing, 15(3), 279-303.

Audretsch, D.B., \& Peña-Legazkue, I. (2012). Entrepreneurial activity and regional competitiveness: An introduction to the special issue. Small Business Economics, 39, 531-537.

Barreto, M., Ryan, M.K., \& Schmitt, M.T. (Eds.). (2009). The glass ceiling in the 21 st century: Understanding barriers to gender equality. American Psychological Association. https://doi.org/10.1037/11863-000

Bellucci, A., Borisov, A., \& Zazzaro, A. (2010). Does gender matter in bank-firm relationships? Evidence from small business lending. Journal of Banking \& Finance, 34(12), 2968. Retrieved from https:/www-proquest-com.proxy-ms.researchport.umd.edu/scholarly-journals/does-gendermatter-bank-firm-relationships/docview/756353162/se-2?accountid=12557

Bertrand, M. (2018). Coase Lecture - The Glass Ceiling. Economica, 85(338), 0013-0427. https://doi.org/10.1111/ecca.12264 
Bird, B., \& Brush, C. (2002). A gendered perspective on organizational creation: ET\&P. Entrepreneurship Theory and Practice, 26(3), 41-65. Retrieved from https://www-proquestcom.proxy-ms.researchport.umd.edu/scholarly-journals/gendered-perspective-on-organizationalcreation/docview $/ 213808611 /$ se-2?accountid $=12557$

Birley, S. (1989). Female entrepreneurs: Are they really any different? Journal of Small Business Management, 27(1), 32. Retrieved from https:/www-proquest-com.proxyms.researchport.umd.edu/scholarly-journals/female-entrepreneurs-are-they-reallyany/docview/220952699/se-2?accountid $=12557$

Blair, C. (2012). Women and entrepreneurship: More power to you. OECD Observer, (288), 66.

Blau, F., \& Kahn, L. (2017). The Gender Wage Gap: Extent, Trends, and Explanations. Journal of Economic Literature, 55(3), 789-865.

Bosse, D.A., \& Taylor, P.L., III. (2012). The second glass ceiling impedes women entrepreneurs. Journal of Applied Management and Entrepreneurship, 17(1), 52-68. Retrieved from https://wwwproquest-com.proxy-ms.researchport.umd.edu/scholarly-journals/second-glass-ceiling-impedeswomen-entrepreneurs/docview/927944808/se-2?accountid=12557

Bruckmueller, S., Ryan, M., Rink, F., \& Haslam, S. (2014). Beyond the Glass Ceiling: The Glass Cliff and Its Lessons for Organizational Policy. Social Issues and Policy Review, 8, 202-232.

Bruni, A., Gherardi, S., \& Poggio, B. (2004). Entrepreneur-mentality, gender and the study of women entrepreneurs. Journal of Organizational Change Management, 17(3), 256-268. http://dx.doi.org.proxy-ms.researchport.umd.edu/10.1108/09534810410538315

Brush, C., Edelman, L.F., Manolova, T., \& Welter, F. (2019). A gendered look at entrepreneurship ecosystems. Small Business Economics, 53(2), 393-408. http://dx.doi.org.proxyms.researchport.umd.edu/10.1007/s11187-018-9992-9

Brush, C.G., Wong-MingJi, D., \& Sullivan, S.E. (1999). Women entrepreneurs: Moving beyond the glass ceiling. Academy of Management: The Academy of Management Review, 24(3), 585-586. Retrieved from https://www-proquest-com.proxy-ms.researchport.umd.edu/scholarlyjournals/women-entrepreneurs-moving-beyond-glass-ceiling/docview/210978456/se2? accountid $=12557$

Buckalew, E., Konstantinopoulos, A., Russell, J., \& El-Sherbini, S. (2012). The future of female CEOs and their glass ceiling. Journal of Business Studies Quarterly, 3(4), 145-153. Retrieved from https://www-proquest-com.proxy-ms.researchport.umd.edu/scholarly-journals/future-femaleceos-their-glass-ceiling/docview/1036929638/se-2?accountid=12557

Carter, S. (2000). Improving the numbers and performance of women-owned businesses: Some implications for training and advisory services. Education \& Training, 42(4), 326-334. http://dx.doi.org.proxy-ms.researchport.umd.edu/10.1108/00400910010373732

Carter, R.B., \& Van Auken, H. (2007). Capital acquisition attitudes: Gender and experience. The Journal of Entrepreneurial Finance \& Business Ventures, 12(2), 55-73. Retrieved from https://wwwproquest-com.proxy-ms.researchport.umd.edu/scholarly-journals/capital-acquisition-attitudesgender-experience/docview/1030134682/se-2?accountid=12557

Castrillon, C. (2019). Why more women are turning to entrepreneurship. Retrieved from https://www.forbes.com/sites/carolinecastrillon/2019/02/04/why-more-women-are-turning-toentrepreneurship/?sh=14ec252c542a

Catley, S., \& Hamilton, R.T. (1998). Small business development and gender of owner. The Journal of Management Development, 17(1), 75-82. http://dx.doi.org.proxy-ms.researchport.umd.edu/10. 1108/02621719810368718

Cavalluzzo, K.S., Cavalluzzo, L.S., \& Wolken, J.D. (2002). Competition, small business financing and discrimination: Evidence from a new survey. The Journal of Business, 75(4), 641-679. Retrieved from https://www-proquest-com.proxy-ms.researchport.umd.edu/scholarly-journals/competitionsmall-business-financing/docview/236352820/se-2?accountid $=12557$

Chaganti, R., \& Parasuraman, S. (1996). A study of the impacts of gender on business performance and management patterns in small businesses: ET\&P. Entrepreneurship Theory and Practice, 21(2), 
73-75. Retrieved from https://www-proquest-com.proxy-ms.researchport.umd.edu/scholarlyjournals/study-impacts-gender-on-business-performance/docview/213809552/se2? accountid $=12557$

Coleman, S. (2007). Women-Owned Firms and Growth. Journal of Business and Entrepreneurship, 19(2), 31-44. Retrieved from https://www-proquest-com.proxy-ms.researchport.umd.edu/scholarlyjournals/women-owned-firms-growth/docview/214230803/se-2?accountid=12557

Coughlin, J.H., \& Thomas, A. (2002). The Rise of Women Entrepreneurs. Quorum Books, Westport, Connecticut.

Cowling, M., \& Taylor, M. (2001). Entrepreneurial women and men: Two different species? Small Business Economics, 16(3), 167-175. Retrieved from https://www-proquest-com.proxyms.researchport.umd.edu/scholarly-journals/entrepreneurial-women-men-two-differentspecies/docview/220957501/se-2?accountid $=12557$

Cromie, S. (1987). Motivations of aspiring male and female entrepreneurs: SUMMARY. Journal of Occupational Behavior (1986-1998), 8(3), 251. Retrieved from https://www-proquestcom.proxy-ms.researchport.umd.edu/scholarly-journals/motivations-aspiring-male-femaleentrepreneurs/docview/227960015/se-2?accountid=12557

Deakins, D., \& Whittam, G. (2000). Business start-up: Theory, practice and policy. In S. Carter \& D. Jones-Evans (Eds.), Enterprise and Small Business: Principles, Practice and Policy. Financial Times Prentice-Hall, London.

Du Rietz, A., \& Henrekson, M. (2000). Testing the female underperformance hypothesis. Small Business Economics, 14(1), 1-10. Retrieved from https://www-proquest-com.proxyms.researchport.umd.edu/scholarly-journals/testing-female-underperformancehypothesis/docview/220946775/se-2?accountid=12557

Fairlie, R.W., \& Fossen, F.M. (2018). Opportunity versus Necessity Entrepreneurship: Two Components of Business Creation. CESifo Working Paper Series No. 6854. SSRN. Retrieved from https://ssrn.com/abstract=3140340

Fielden, S.L., Davidson, M.J., Dawe, A J., \& Makin, P.J. (2003). Factors inhibiting the economic growth of female owned small businesses in north west England. Journal of Small Business and Enterprise Development, 10(2), 152. http://dx.doi.org.proxy-ms.researchport.umd.edu/10.1108/ 14626000310473184

Forbes. (2020). Why Women Entrepreneurs Are Critical to Economic Growth. Retrieved from https:/www.forbes.com/sites/forbesbusinesscouncil/2020/05/18/why-women-entrepreneurs-arecritical-to-economic-growth/?sh=2ddab9774523

Gatewood, E.J., Shaver, K.G., Powers, J.B., \& Gartner, W.B. (2002). Entrepreneurial expectancy, task effort, and performance: ET\&P. Entrepreneurship Theory and Practice, 27(2), 187-206. Retrieved from https://www-proquest-com.proxy-ms.researchport.umd.edu/scholarlyjournals/entrepreneurial-expectancy-task-effort/docview/213808741/se-2?accountid=12557

Global Entrepreneurship Monitor (GEM). (2020). Global Entrepreneurship Monitor 2019/2020 Global Report. Retrieved from https://www.gemconsortium.org/report/gem-2019-2020-global-report

Hadary, S.G. (2010, May 17). What's holding back women entrepreneurs?: Women-owned businesses are a lot smaller than men-owned companies; blame it partly on the women themselves -- and partly on the people and institutions they deal with. Wall Street Journal. Retrieved from https://wwwproquest-com.proxy-ms.researchport.umd.edu/newspapers/whats-holding-back-womenentrepreneurs-owned/docview/288052462/se-2?accountid $=12557$

Haltiwanger, J., Jarmin, R., \& Miranda, J. (2013). Who Creates Jobs? The Review of Economics and Statistics, 95(2), 347-361.

Hegewisch, A., \& DuMonthier, A. (2016). The Gender Wage Gap: 2015; Earnings Differences by Race and Ethnicity. Institute for Women's Policy Research.

Heilbrunn, S. (2004). Impact of gender on difficulties faced by entrepreneurs. International Journal of Entrepreneurship and Innovation, 5(3), 159-165. Retrieved from https://www-proquestcom.proxy-ms.researchport.umd.edu/scholarly-journals/impact-gender-on-difficulties-faced- 
entrepreneurs/docview/217837899/se-2?accountid $=12557$

Hersby, M.D., Ryan, M.K., \& Jetten, J. (2009). Getting together to get ahead: The impact of social structure on women's networking. British Journal of Management, 20(4), 415. Retrieved from https://www-proquest-com.proxy-ms.researchport.umd.edu/scholarly-journals/getting-togetherget-ahead-impact-social/docview/229441599/se-2?accountid=12557

Hill, F.M., Leitch, C.M., \& Harrison, R.T. (2006). Desperately Seeking Finance? The Demand for Finance by Women-owned and -led Businesses. Venture Capital, 8(2), 159-182.

Hisrich, R.D., \& Brush, C. (1984). The woman entrepreneur: Management skills and business problems. Journal of Small Business Management, 22(1), 30. Retrieved from https://wwwproquest-com.proxy-ms.researchport.umd.edu/scholarly-journals/woman-entrepreneurmanagement-skills-business/docview/220995700/se-2?accountid=12557

Hollister, M.N. (2004). Does firm size matter anymore? The new economy and firm size wage effects. American Sociological Review, 69(5), 659-676. Retrieved from https://www-proquestcom.proxy-ms.researchport.umd.edu/scholarly-journals/does-firm-size-matter-anymore-neweconomy-wage/docview/218793848/se-2?accountid=12557

Hughes, K.D. (2003). Pushed or Pulled? Women's Entry into Self-Employment and Small Business Ownership. Gender, Work and Organization, 10(4), 433-454.

Jennings, J., \& Mc Dougald, M. (2007). Work-family interface experiences and coping strategies: Implications for entrepreneurship research and practice. Academy of Management Review, 32(3), 747-60.

Klettner, A., Clarke, T., \& Boersma, M. (2016). Strategic and Regulatory Approaches to Increasing Women in Leadership: Multilevel Targets and Mandatory Quotas as Levers for Cultural Change. J Bus Ethics, 133, 395-419. https://doi.org/10.1007/s10551-014-2069-z

Kerr, W.R., \& Nanda, R. (2009). Financing Constraints and Entrepreneurship. Harvard Business School Entrepreneurial Management Working Paper No. 10-013. SSRN. Retrieved from https://ssrn.com/abstract=1447503 or http://dx.doi.org/10.2139/ssrn.1447503

Kirkwood, J. (2009). Motivational factors in a push-pull theory of entrepreneurship. Gender in Management: An International Journal, 24(5), 346-364. https://doi.org/10.1108/17542410910968805

Lerner, J. (2009), Boulevard of broken dreams: Why public efforts to boost entrepreneurship and venture capital have failed - and what to do about it. Princeton: Princeton University Press.

Lerner, M., \& Almor, T. (2002). Relationships among strategic capabilities and the performance of women-owned small ventures. Journal of Small Business Management, 40(2), 109-125. Retrieved from https://www-proquest-com.proxy-ms.researchport.umd.edu/scholarlyjournals/relationships-among-strategic-capabilities/docview/221000683/se-2?accountid=12557

Leyden, D. (2016). Public-sector entrepreneurship and the creation of a sustainable innovative economy. Small Business Economics, 46(4), 553-564.

Loscocco, K.A., \& Robinson, J. (1991). Barriers To Women's Small-Business Success In The United States. Gender \& Society, 5(4), 511-532. https://doi.Org/10.1177/089124391005004005

Madill, J., Riding, A.L., \& Haines, G.H. (2006). Women entrepreneurs: Debt financing and banking relationships. Journal of Small Business and Entrepreneurship, 19(2), 121-142. Retrieved from https://www-proquest-com.proxy-ms.researchport.umd.edu/scholarly-journals/womenentrepreneurs-debt-financing-banking/docview/214502292/se-2?accountid=12557

Manolova, T.S., Brush, C.G., \& Edelman, L.F. (2008). What do women entrepreneurs want? Strategic Change, 17(3), 69. Retrieved from https:/www-proquest-com.proxy-ms.researchport.umd.edu/ scholarly- journals/ what-do-women-entrepreneurs-want/docview/216503120/se2? accountid $=12557$

Manolova, T., Manev, I., Carter, N., \& Gyoshev, B. (2006). Breaking the Family and Friends Circle: Predictors of External Financing Usage among Men and Women Entrepreneurs in a Transitional Economy. Venture Capital, 8(2), 109-132.

Marlow, S., \& Patton, D. (2005). All credit to men? Entrepreneurship, finance, and gender. 
Entrepreneurship Theory \& Practice, 29(6), 717-35.

McClelland, E., Swail, J., Bell, J., \& Ibbotson, P. (2005). Following the pathway of female entrepreneurs: A six-country investigation. International Journal of Entrepreneurial Behaviour and Research, 11(2), 84-107.

Minniti, M., \& Naudé, W. (2010). Introduction: What do we know about the patterns and determinants of female entrepreneurship across countries? The European Journal of Development Research, 22(3), 277-293. http://dx.doi.org.proxy-ms.researchport.umd.edu/10.1057/ejdr.2010.17

Muravyev, A., Talavera, O., \& Schäfer, D. (2009). Entrepreneurs' gender and financial constraints: Evidence from international data. Journal of Comparative Economics, 37(2), 270-286. http://dx.doi.org.proxy-ms.researchport.umd.edu/10.1016/j.jce.2008.12.001

National Women's Business Council (NAWBO). (2010). National Association of Women Business Owners - Women Business Owner Statistics. Retrieved from http://nawbo.org/resources/womenbusiness-owner-statistics

Nixdorff, J.L., \& Rosen, T.H. (2010). The glass ceiling women face: An examination and proposals for development of future women entrepreneurs. New England Journal of Entrepreneurship, 13(2), 71-87. Retrieved from https://www-proquest-com.proxy-ms.researchport.umd.edu/scholarlyjournals/glass-ceiling-women-face-examination-proposals/docview/862750175/se2?accountid $=12557$

Orhan, M., \& Scott, D. (2001). Why women enter into entrepreneurship: An explanatory model. Women in Management Review, 16(5), 232-243. http://dx.doi.org.proxyms.researchport.umd.edu/10.1108/09649420110395719

Orser, B.J., Riding, A.L., \& Manley, K. (2006). Women entrepreneurs and financial capital: ET\&P. Entrepreneurship Theory and Practice, 30(5), 643-665. http://dx.doi.org.proxy-ms.researchport. umd. edu/ 10. 1111/ j.1540-6520.2006.00140.x

Pandey, S., \& Amezcua, A.S. (2020). Women's business ownership and women's entrepreneurship through the lens of U.S. federal policies. Small Bus Econ, 54, 1123-1152. https://doi.org/10.1007/s11187-018-0122-5

Paz, R.B., \& Cabrer-Borrás, B. (2018). Necessity and opportunity entrepreneurs: Survival factors. International Entrepreneurship and Management Journal, 14(2), 249-264. http://dx.doi.org.proxy-ms.researchport.umd.edu/10.1007/s11365-018-0504-9

Pellegrino, E.T., \& Reece, B.L. (1982). Perceived formative and operational problems encountered by female entrepreneurs in retail and service firms. Journal of Small Business Management, 20(2), 15. Retrieved from https://www-proquest-com.proxy-ms.researchport.umd.edu/scholarlyjournals/perceived-formative-operational-problems/docview/220995389/se-2?accountid=12557

Rico, B., Wild, P., Alberton, S., \& Fredrik, H. (2017). Global Entrepreneurship Monitor 2016/2017.

Robb, A., \& Coleman, S. (2014). Financing high growth women-owned enterprises: Evidence from the United States. Washington: International Council for Small Business (ICSB). Retrieved from https://www-proquest-com.proxy-ms.researchport.umd.edu/conference-papersproceedings/financing-high-growth-women-owned-enterprises/docview/1796775679/se2? accountid $=12557$

Robb, A., \& Wolken, J. (2002). Firm, owner, and financing characteristics: Differences between femaleand male-owned small businesses. St. Louis: Federal Reserve Bank of St Louis. Retrieved from https://www-proquest-com.proxy-ms.researchport.umd.edu/working-papers/firm-ownerfinancing-characteristics-differences/docview/1698096249/se-2?accountid=12557

Roper, S., \& Scott, J.M. (2009). Perceived financial barriers and the start-up decision: An econometric analysis of gender differences using GEM data. International Small Business Journal, 27(2), 149. http://dx.doi.org.proxy-ms.researchport.umd.edu/10.1177/0266242608100488

Rosa, P., Hamilton, D., Carter, S., \& Burns, H. (1994). The impact of gender on small business management: Preliminary findings of a British study. International Small Business Journal, 12(3), 25. http://dx.doi.org.proxy-ms.researchport.umd.edu/10.1177/0266242694123002

Scherer, R.F., Brodzinski, J.D., \& Wiebe, F.A. (1990). Entrepreneur career selection and gender: A 
socialization approach. Journal of Small Business Management, 28(2), 37. Retrieved from https://www-proquest-com.proxy-ms.researchport.umd.edu/scholarly-journals/entrepreneurcareer-selection-gender/docview/221001308/se-2?accountid=12557

Sena, V., Scott, J., \& Roper, S. (2012). Gender, borrowing patterns and self-employment: Some evidence for England. Small Business Economics, 38(4), 467-480. http://dx.doi.org.proxy-ms.researchport. umd.edu/10.1007/s11187-010-9272-9

Shaw, E., Marlow, S., Lam, W., \& Carter, S. (2009). Gender and entrepreneurial capital: Implications for firm performance. International Journal of Gender and Entrepreneurship, 1(1), 25-41. http://dx.doi.org.proxy-ms.researchport.umd.edu/10.1108/17566260910942327

Simonin, M. (2006). Women entrepreneurship. Business Strategy and International Business, pp. 91-167. Helsinki University of Technology.

Stam, E. (2015). Entrepreneurial Ecosystems and Regional Policy: A Sympathetic Critique. European Planning Studies, 23.

Stam, E., \& Spigel, B. (2016). Entrepreneurial Ecosystems. Working Papers 16-13, Utrecht School of Economics. Retrieved from https://dspace.library.uu.nl/bitstream/handle/1874/347982/16_13.pdf

Still, L., \& Timms, W. (2000). "I Want to Make a Difference": Women Small Business Owners: Their Businesses, Dreams, Lifestyles, and Measures of Success. In E. Douglas (Ed.), Entrepreneurial SMEs - Engines for Growth in the Millenium (Brisbane, Australia ed., Vol. CD-ROM, pp. N/A). International Council for Small Business (ICSB).

Stinchcombe, A.L. (1965). Organizations and Social Structure. In J. March (Ed.), Handbook of Organizations (pp. 153-193). Chicago: Rand McNally.

Storey, D.J. (1994). New firm growth and bank financing. Small Business Economics, 6(2), 139. Retrieved from https://www-proquest-com.proxy-ms.researchport.umd.edu/scholarlyjournals/new-firm-growth-bank-financing/docview/220905060/se-2?accountid=12557

Thornton, G. (2018). Women in business: Beyond policy to progress. Report. Grant Thornton. London. Retrieved from https://www. grantthornton. global/globalassets/1.-member-firms/global/insights/ women-in-business/grant-thornton-women-in-business-2018-report.pdf

Treichel, M.Z., \& Scott, J.A. (2006). Women-Owned Businesses and Access to Bank Credit: Evidence from Three Surveys Since 1987. Venture Capital, 8(1), 51-67.

Ufuk, H., \& Ozgen, O. (2001). Interaction between the business and family lives of women entrepreneurs in Turkey: JBE. Journal of Business Ethics, 31(2), 95-106. Retrieved from https://www-proquest -com.proxy-ms.researchport.umd.edu/scholarly-journals/interaction-between-business-familylives-women/docview/198058414/se-2?accountid=12557

Verheul, I., \& Thurik, R. (2001). Start-up capital: 'Does gender matter?' Small Business Economics, 16(4), 329-345. Retrieved from https://www-proquest-com.proxy-ms.researchport.umd.edu/scholarlyjournals/start-up-capital-does-gender-matter/docview/220947259/se-2?accountid=12557

Vossenberg, S. (2013). Women entrepreneurship promotion in developing countries: What explains the gender gap in entrepreneurship and how to close it? St. Louis: Federal Reserve Bank of St Louis. Retrieved from https://www-proquest-com.proxy-ms.researchport.umd.edu/working-papers/ women-entrepreneurship-promotion-developing/docview/1698798375/se-2?accountid=12557

Walker, E.A., \& Webster, B.J. (2007). Gender, age and self-employment: Some things change, some stay the same. Women in Management Review, 22(2), 122-135. http://dx.doi.org.proxyms.researchport. umd.edu/10.1108/09649420710732088

Watkins, J.M., \& Watkins, D.S. (1983). The female entrepreneur: Her background and determinants of business choice_-some British data. Frontiers of Entrepreneurship Research, pp. 271-288. 